\title{
Fallacy, sacrilege, betrayal and conspiracy: the cultural construction of opposition to immunisation in India
}

\author{
Niels Brimnes
}

\section{Immunisation in India - an outline}

In January 1819 the Madras Courier published an interesting note by Calvi Virumbon, in which it was claimed that vaccination against smallpox was known in India before Jenner's famous discovery in 1796. Virumbon wrote that he had discovered an ancient text in Sanskrit describing a way to avoid smallpox, which was indistinguishable from vaccination. ${ }^{1}$ Together with other more or less convincing references to the existence of pre-Jennerian vaccination in India, Virumbon's claim caused significant interest over the next century. Today, however, there seems to be agreement that the claim was a 'pious fraud' made by a British civil servant in an attempt to inscribe vaccination into the Indian medical tradition, which already included the practice of variolation inoculation of real smallpox matter - as a preventive against smallpox. ${ }^{2}$ This fraud is nevertheless interesting as an attempt to 'indigenise' a foreign medical practice, which the British expected to be well received by the Hindus due its connection with the sacred cow.

The cowpox vaccine reached India via Persia in 1802, and the colonial medical authorities immediately began to promote it. In many areas they had to convince Indians to shift from variolation to vaccination, either because the former was an established indigenous practice or because it had been actively promoted by the colonial authorities. ${ }^{3}$ It was in this context that the colonial authorities expected to capitalise on the connection between vaccination and the cow. In the Asiatic Annual Register from 1803 it was, for instance, noted that: 'From the veneration in which 
the animal is held by Hindus it requires only an intimation that such a blessing was within their reach, to ensure its earliest dissemination throughout this division or class of the inhabitants of Bombay. ${ }^{4}$

The hopes that vaccination was particularly well attuned to Indian cultural sensibilities were, however, soon dashed, as Indians turned out to be no less reluctant than other populations across the world in accepting an unknown practice performed directly on their - or their infants- bodies. By contrast, to the extent that religious and moral considerations had any impact on the dissemination of vaccination in India, they tended to work against it.

Vaccination against smallpox made only slow and uneven progress in colonial India. Throughout the nineteenth century vaccination was a crude and unreliable operation, and it was not obvious that it was superior to variolation in preventing smallpox. ${ }^{5}$ However, the introduction of lymph derived from calves towards the end of the century and the establishment of large vaccine-producing units from the first decades of the twentieth century secured a constant supply of more reliable vaccine. ${ }^{6}$ Together with the gradual introduction of revaccination these developments meant that vaccination made more progress, and it was one of the few public health interventions in British India that is believed to have had an impact on mortality figures in the first part of the twentieth century. Through most of the nineteenth century the term vaccination invariably meant vaccination against smallpox, but from the 1890s other types of immunisation were introduced and also referred to as 'vaccination'. Most notably, the Russian bacteriologist Waldemar Haffline was based in India from 1893, where he tested vaccines against cholera and plague. ${ }^{8}$

Indians often reacted to vaccination with indifference or resistance. Some might have rejected it, because it was foreign and unknown or because it was seen as secular rival to the religiously inscribed practice of variolation. In such instances, vaccination might have served as 'a site of conflict between malevolent British intent and something Indian, something sacred, that was under threat of violation and destruction.9 Many more might have avoided vaccination for more practical reasons: because it was difficult to access, harmful, unpleasant and in many cases without effect. ${ }^{10}$ Immunisation against plague caused significant opposition, as did most of the other draconian measures introduced by the colonial state during the plague emergency around 1900." In the 
twentieth century a more articulate and organised opposition emerged, which often drew on the activities and arguments of the strong antivaccination movement in Britain. They did, however, never form a united front against vaccination in India. ${ }^{12}$

By 1947 immunisation was an established and integrated part of the public health service in India. In 1946 a committee under the chairmanship of Sir Joseph Bhore published a report with suggestions for the development of the health services in post-war - and presumably postcolonial - India. The report was widely referred to in the decades after 1947 , even if actual politics often differed from its recommendations. It advocated the doctrine of 'social medicine', which favoured broad sanitary interventions over narrow, technology-driven advances against specific diseases. However, if the report warned against believing that proper health could 'be achieved through a bottle of medicine or a surgical operation'; it nevertheless strongly supported vaccination. ${ }^{13}$ Noting that India had the highest incidence of smallpox among all countries featuring in League of Nations statistics, it declared vaccination to be 'the quickest and the most effective means of controlling the disease' and deemed it to be 'essential that primary vaccination should be made compulsory throughout the country without delay.14 The report also favoured immunisation against cholera and plague. ${ }^{15}$

In the first decade after independence diseases other than smallpox, cholera and plague took centre stage in India. Top priority was now given to malaria and tuberculosis, and to some extent vaccination against smallpox suffered from this development. ${ }^{16}$ The new focus brought, on the other hand, the controversial BCG vaccine against tuberculosis to India. In late 1948 the Government of India secured international assistance in introducing mass BCG vaccination. The Indian BCG campaign developed into the largest immunisation campaign the world had seen, and the goal was to reach all Indians below the age of 25 (estimated at 170 million people) by the end of the second five-year plan period in 1961. It was, however, difficult to overcome logistical challenges and to keep pace with population growth, and the campaign continued until BCG was incorporated into the general immunisation programme in $1978 .{ }^{17}$ On top of this, the campaign also encountered a well-articulated opposition, which is analysed here.

From the late 1950s the interest in smallpox returned as WHO began to promote the goal of global eradication. A resolution made by the 
Twelfth World Health Assembly in 1959 marked the official beginning of the eradication effort, and also led to increasing activities in India. ${ }^{18}$ A National Smallpox Eradication Programme (NSEP) was launched in 1962, which aimed to reach 80 per cent coverage in three years. ${ }^{19}$ Despite access to international assistance the programme was a disappointment. With only 44.9 per cent of the population vaccinated, it was - in Sanjoy Bhattacharya's assessment - obvious to all involved that 'the NSEP timetable had gone completely awry and, even more worryingly, it was very apparent that no one was completely sure when - or if smallpox would ever be expunged from India. ${ }^{20}$ Marked progress did not come until after the launching of an 'Intensified Campaign' (INSEP) in 1973. INSEP meant more national and international funding, a shift to the 'containment and surveillance' strategy and enhanced focus on the four major endemic states Bihar, Madhya Pradesh, Uttar Pradesh and West Bengal. ${ }^{21}$ In May 1975 the last indigenous case of smallpox was reported from Bihar and two years later India was certified free from smallpox. ${ }^{22}$ Vaccination had achieved its greatest triumph in India.

In 1974 - while India was still struggling to eradicate smallpox WHO launched its 'Expanded Programme of Immunization', which included vaccines against six childhood diseases: diphtheria, tetanus, whooping cough, polio, measles and tuberculosis (BCG). This programme was adopted in India from 1978. In 1985 the programme was renamed the Universal Immunisation Programme (UIP) and an attempt made to extent it to the entire country. ${ }^{23}$ One recent account has described UIP as the largest immunisation programme in the world, catering annually to 27 million infants and 30 million pregnant women. The same account also notes, however, that after twenty-five years the coverage of UIP is still poor in many areas and that millions of infants are not immunised according to schedule. ${ }^{24}$ In 1994, following another call from the WHO for a single-disease eradication programme, India intensified its efforts to eradicate polio. The means to reach this goal was another mass immunisation campaign, known as the Pulse Polio Programme. While the polio programme was met with criticism from some professional quarters, India has succeeded in eliminating polio from its territory and is at the time of writing expecting to be officially certified as polio free. ${ }^{25}$ From the controversial attempt to control tuberculosis with the BCG vaccine to the removal of polio from Indian soil, independent India's immunisation record is, therefore, largely one of 
acceptance and implementation of the international agenda set by WHO. The responses to immunisation in post-colonial India did not deviate much from those seen in colonial India. The majority of Indians accepted immunisation and reluctance to accept vaccines was often due to indifference or vague fears about imperfectly understood practices. $^{26}$

In the official WHO account of the eradication of smallpox this type of response has been conveniently couched as 'cultural and religious' resistance stemming from 'traditions and folklore', but in an analysis of resistance to vaccination in the final stages of smallpox eradication, Paul Greenough has linked such opposition to the coercive measures employed by campaign officials. ${ }^{27}$ Organised political or ideological opposition was, however, rare. The cases analysed by Greenough were spontaneous and local, and while Bhattacharya does identify more politically motivated opposition to the smallpox eradication drive in the 1970s, he also notes that it was 'relatively easy to isolate. ${ }^{28}$ Organised, political or ideological opposition to immunisation was exceptional, and the following sections analyse four instances of this type of opposition, in order to understand how immunisation was constructed in relation to ideas about being Indian, the features of Indian society and India's place in the world.

\section{Immunisation as fallacy}

In 1921 N. F. Billimoria of the Bombay Humanitarian League - an animal welfare organisation - published a pamphlet against vaccination entitled Vaccination and Small-pox. The pamphlet consisted of three parts: a piece written by Billimoria himself, a piece written by the Secretary to the National Anti-Vaccination League in Britain, Ms Lily Loat, and a compilation of authoritative opinions by influential men (and a single woman). Billimoria's own contribution 'Vaccination: A Fallacy' attacked the practice on several fronts. He duly began with the pain caused to the calves used in the production of vaccine lymph, but soon turned to the more 'utilitarian' argument that vaccination had no effect. Referring to official statistics he claimed that there were as many deaths from vaccination as from smallpox itself in Britain in 1914-15; he saw a correlation between a falling vaccination coverage and fewer cases of smallpox in England and Wales between 1912 and 1917; and 
he asked why Germany and Japan with their strict regimes of compulsory vaccination still had a considerable number of smallpox cases. In a short digression to Indian conditions Billimoria mentioned that despite the efforts to vaccinate Indians, there were several hundred deaths from smallpox in Bombay city every month. He also claimed that vaccination made 'men more susceptible to other diseases', and questioned the 'craze' for giving sera and vaccines against any possible ailment. ${ }^{29}$

This led to a more general argument about medical strategy. Referring to the well-known example of Leicester, where smallpox was quite successfully combatted without vaccination, he juxtaposed sanitation to vaccination. He quoted a British professor to the effect that in the English city of Leicester, which was famous for rejecting vaccination: 'we have real immunity, real protection; and it is obtained by attending to sanitation and isolation, coupled with the almost total neglect of vaccination'. Applying this opposition to the Bombay slums, he asked: 'Now if vaccination has nothing whatever to do with sanitary measures, why vaccination could not prevent the epidemics in the overcrowded and filthy areas? And yet we are taught by our medical friends that small-pox has nothing to do with sanitary measures. ${ }^{30}$ Billimoria also drew on moral arguments about the right to intervene in the order of nature and he invoked the purity and vitality of the nation's youth: 'We want to bring our children into such a splendid condition of health by means of pure milk, pure diet, pure air and pure living generally; we want to bring the nation generally into such a condition of health as will resist any onslaught of such poisons as small-pox \&c. ${ }^{31}$ Vaccination was not only cruel to animals, it was also useless, a violation of the relation between man and nature and it harmed the strength of the nation.

Lily Loat's contribution 'Vaccination and Small-pox in India', argued along the same lines. She fielded three objections to vaccination: the cruelty committed towards lymph-producing animals, the pain and risk suffered by children taking the vaccine, and a lack of measurable effects. In relation to the latter argument and after going through official statistics, she concluded that vaccination had 'not had the slightest effect in diminishing small-pox in India. To the contrary, she found that death rates in India had gone up with the increase of vaccination. ${ }^{32}$ Loat was also worried about purity, albeit in a more direct way. Vaccines were, 
she argued, 'swarming with micro-organisms' and the ultimate origin of material used in vaccination remained obscure. ${ }^{33}$ If Billimoria was concerned about the purity of the national body, Loat warned against pollution of individual bodies. Finally, Loat saw herself as the spokesperson for 'the vast mass of inarticulate poverty-stricken Indians', who could not speak for themselves. Yet, the conventional colonial rhetoric was turned upside down, when she declared that the Indian masses were ready to throw off the superstitious belief in vaccination; the problem rested with the educated classes, which had imbibed Western ideas. ${ }^{34}$ There was no reason why India should follow the false path taken by a superstitious Britain.

Perhaps the most salient feature of pamphlet was the predominance of the British experience. Most of the figures came from Britain, and most of the references were to British Government reports and information appearing in the organ of the Anti-Vaccination League in Britain, The Vaccination Inquirer. This impression is reinforced by the compilation of authoritative opinions in the third and last part of the pamphlet. These were overwhelmingly British, with Florence Nightingale being the sole woman. It would seem that Billimoria's and Loat's opposition to vaccination was inspired by, and imported from, Britain. If vaccination was inappropriate in Britain, it would be inappropriate in India for the same reasons. There was no specifically Indian element in the reservations raised in Billimoria's pamphlet, and I would characterise this type of opposition to immunisation as cosmopolitan.

\section{Vaccination as sacrilege}

A notable - and available - Indian voice absent from Billimoria's collection of opinions against vaccination was Gandhi. Through the early satyagrahas and the non-cooperation campaign Gandhi had by 1921 taken the position as the key figure in the nationalist movement, and he had also articulated views on health issues. From the publication of the well-known pamphlet Hind Swaraj in 1909 Gandhi emerged as a vocal opponent to western medicine. In 1913 he published a series of articles in Indian Opinion under the title 'General Knowledge About Health', which were modified and republished in 1921 as A Guide to Health. ${ }^{35}$ Throughout his life he continued to comment on issues of 
health and medicine and vaccination was among the practices he most fervently criticised. Gandhi had two reservations against vaccination. First it hindered discipline over the body and control over the mind. In Hind Swaraj Gandhi argued that if the doctor did not intervene in the body - with drugs or vaccines - 'nature' would do its work 'and I would have acquired mastery over myself.' ${ }^{36}$ This resembled Billimoria's objection to interfere in the order of nature; and it is noteworthy that Billimoria referred to Spencer rather than Gandhi on this issue. ${ }^{37}$

It also violated his religious instincts, his vegetarianism and his notion of purity. Many medical remedies contained alcohol or animal substances, and in one of the articles published in 1913 he was very clear about his views:

Vaccination seems to be a savage custom. It is one of the poisonous superstitions of our times the equal of which is not to be found even among so called primitive societies ... Vaccination is a filthy remedy. Vaccine from an infected cow is introduced into our bodies; more, even vaccine from an infected human being is used ... I personally feel that in taking this vaccine we are guilty of a sacrilege. ${ }^{38}$

By 1929 Gandhi held the same views. In a comment on F. L. Brayne's book Village Uplift in India Gandhi commented that various forms of immunisation were 'soul destroying remedies making man a weakling dying many times before his natural death. ${ }^{39}$ Gandhi was ready to admit that vaccination gave 'a sort of temporary immunity from smallpox', but he also affirmed his religious objections to the practice. ${ }^{40}$ In the weekly newspaper Navajivan he wondered how 'vegetarians can ever take such vaccine' and in a private letter he described vaccination as 'tantamount to partaking of beef. ${ }^{41}$ In this way vaccination became emblematic of all that was wrong with western medicine.

It would not, however, do justice to Gandhi to see him as simply rejecting western medicine. Although he identified doctors in Hind Swaraj as one of the great evils of western civilisation, and in the same year in a private letter for the first - but not the last - time described western medicine as 'the essence of black magic', he did acknowledge and approve the scientific approach of the discipline. The problem was the way it was used. ${ }^{42}$ When Gandhi opened the 'Tibbia' medical college in Delhi in 1921 he first reiterated his statement that western medicine was 'black magic', but immediately continued: 'Having said that much 
I would like to pay my humble tribute to the spirit of research that fires the modern scientists. My quarrel is not against that spirit. My complaint is against the direction that the spirit has taken. ${ }^{34}$ To a German interviewer, in 1937, Gandhi explained that he did not despise all medical treatment that came from the West and emphasised safe maternity and the care of infants as fields where India could learn from the West. ${ }^{44}$ It would be more accurate to say that Gandhi's criticism focused on a number of specific practices, which he found particularly objectionable, and that various forms of immunisation were prominent among them.

Instead, he found the virtues of science in two other fields related to health: nutrition and sanitation. In Gandhi's universe they seem to have been complementary; the first dealing with inward and personal purity, the latter with outward corporate cleanliness. Both Joseph Alter and Sunil Amrith have noted how Gandhi turned to the emerging science of nutrition and the authority of the League of Nations Health Organization to substantiate his claim for the importance of a balanced diet. ${ }^{45}$ But personal cleanliness and a proper diet were not enough. As he wrote in Young India in 1929, Indians had a reputation for being a personally clean people, but that cleanliness was bought 'at the expense of our neighbours ... We are clean as individuals but not as members of the society or the nation of which the individual is but a tiny part. ${ }^{36}$ In order to achieve cleanliness at the corporate level Gandhi turned to sanitation.

As early as 1913 Gandhi discovered that 'hygiene' was a science distinct from, and superior to, medicine because it was preventive rather than curative. ${ }^{47}$ In 1921, he stated this even more clearly: 'The science of sanitation is infinitely more ennobling, though more difficult of execution, than the science of healing. ${ }^{38}$ The issue of sanitation surfaced more prominently in Gandhi's writings as he became engaged in village reconstruction work from the 1920 s and featured in his 'constructive programme' from the $1940 \mathrm{~s}^{49}$

Like Billimoria, Gandhi opposed vaccination and sanitation. In 1929 he advised that 'those who do not get themselves vaccinated ought to know and follow the rules of sanitation', thereby suggesting - as in Billimoria's reference to Leicester - that sanitation was an alternative to vaccination. ${ }^{50}$ Referring to the Bombay slums Billimoria had also suggested that insanitary surroundings would cancel out any 
potentially positive effects of vaccination; but this was not a central part of Gandhi's opposition. His was not an argument about the relative efficacy of vaccination; it was about substituting morally sound sanitary behaviour for an immoral practice.

Gandhi was a genuinely cosmopolitan thinker, who drew inspiration from both Indian and non-Indian sources. He was no great admirer of India's own medical traditions and inspiration for his cherished strategy of village sanitation came from the West. In 1927 he declared that Indians 'have yet got to learn much from the Britisher in the matter of sanitation' and a decade later he told an interviewer that he had 'copied' his ideas about sanitation from the British doctor, George Vivian Poore. ${ }^{51}$ In his specific opposition to vaccination he also looked abroad and referred to the anti-vaccination movement in Britain and its arguments with approval. ${ }^{52}$ A close examination of Gandhi's writings might, therefore, lead one to conclude that his opposition to vaccination was every bit as cosmopolitan as the opposition manifested in Billimoria's pamphlet.

Yet, Gandhi's anti-vaccination rhetoric did assume a particularistic touch. His appearance as the main figure of the Indian nationalist movement and his explicit exploitation of specifically Indian idioms made this inevitable. Identifying western doctors as one of the major evils of western civilisation in the widely circulated Hind Swaraj only reinforced this reading. If European doctors were 'the worst of all', if they violated 'our religious instinct', and if studying European medicine was 'to deepen our slavery', it was indeed obvious to think of vaccination as immoral because it was European. ${ }^{53}$ Later, Gandhi dampened his antiwestern rhetoric on medical issues, but the notion that western medicine was unsuited to Indian conditions persisted. In 1939 he told a medical missionary: 'if I were asked to advise missionaries or Mission Boards, I would ask them not to try to transplant the entire system of Western medicine into India. We could not afford it. There is ever so much to be gleaned and had from the study of indigenous drugs and medicines. ${ }^{54}$ Similarly, in 1947, Gandhi urged Indian doctors and scientists to remain in India, instead of going abroad to pick up the latest curative technologies. He encouraged them to turn their attention to India's numerous villages: 'They will find that all medical men and women can find work to do there. Not in the Western fashion, of course, but in our own fashion in the villages. 55 
From the aggressive rhetoric in Hind Swaraj to the milder insistence on a medical approach suited to the conditions of the Indian villages, Gandhi's position always implied a notion of Indian difference. Despite cosmopolitan inspiration his religiously informed opposition to any kind of immunisation was bound to be understood as an insistence on Indian distinctiveness.

\section{Immunisation as an act of betrayal ${ }^{56}$}

When the Government of India in 1948 invited the Scandinavian 'International Tuberculosis Campaign' (ITC) to assist in the introduction of the BCG vaccine against tuberculosis, it was a manifestation of the modernist aspirations of the new state and its belief in modern technology. The reservations of Gandhi and like-minded people were sidelined as the Government authorities promised that 'BCG constitutes a potent and speedy method of bringing under control the high incidence of tuberculosis which has been spreading rapidly through the country.'57 Those who cared to look would find claims that BCG provided 80 per cent protection and could reduce the tuberculosis problem in India to a fifth over 15-20 years of intensive vaccination. ${ }^{58}$ They would also find, however, that both the safety and the efficacy of BCG were questioned. The effort to control tuberculosis through vaccination triggered, therefore, the largest and best articulated anti-immunisation campaign in post-colonial India - and possibly in the post-colonial world.

The opposition radiated from Madras in South India, but was noted throughout India and even beyond. It began before the first expert from ITC had set foot in India. In November 1948 the former sanitary engineer of the Government of Madras, A. V. Raman, wrote a critical editorial in People's Health; a monthly publication edited and run, it seems, mainly by Raman himself. ${ }^{59}$ As the Indian authorities and Scandinavian experts in February 1949 prepared to inaugurate the BCG vaccination campaign in Madras, Raman raised his voice again. And his opposition to BCG began to appear in newspapers throughout India. On 14 February - just two days before the official inauguration of the campaign - he published a lengthy piece in the most prominent newspaper in the Madras area, The Hindu. ${ }^{60}$ Raman succeeded in putting the Indian authorities on the defensive, and in his opening address P. V. Benjamin - the adviser on tuberculosis to the Government of India - conceded 
that the Government had opted for BCG because it had limited resources and BCG promised to be an affordable solution to an extensive and costly health problem. ${ }^{61}$ Raman collected the contributions to the heated dispute over BCG and published it in the February issue of People's Health, adding an extensive editorial entitled 'BCG What about it? ${ }^{62}$ Until 1951 Raman succeeded in temporarily putting the implementation of BCG vaccination to a halt in Madras, but in other regions his opposition did not have a similar impact. ${ }^{63}$

In July 1951 ITC withdrew from India leaving the field and the challenge to expand mass vaccination to the Indian authorities, WHO and UNICEF. In 1954 Halfdan Mahler, the WHO senior medical officer, believed that it was time to reinvigorate the BCG campaign in Madras State, where it had suffered since Raman's opposition. One reason for this was the resignation of the Chief Minister in the state, Chakravarti Rajagopalachari. Simply known as C. R. or 'Rajaji' among Tamils, he was the prime figure in the nationalist movement in southern India. A close associate of Gandhi and part of the Congress leadership, he had been Chief Minister in the Congress Government of Madras from 1937 to 1939 and held several high offices after 1947. In April 1952 he became once again Chief Minister of Madras, a position he resigned in 1954 after falling out with the dominant faction of the Congress Party in Madras. ${ }^{64}$ Rajagopalachari was also a close friend of Raman and shared his scepticism towards BCG vaccination. From 1952 he communicated his views on BCG in letters to the Union Minister of Health and ardent supporter of BCG, Rajkumari Amrit Kaur. ${ }^{65}$ With his resignation the Indian authorities and their UN supporters were given the opportunity to restart the campaign in Madras, but the former Chief Minister was also free to voice his scepticism in public.

Rajagopalachari first openly challenged BCG in a public speech on 7 May 1955. Benjamin answered Rajagopalachari's criticism in The Hindu only to find a long reply two days later. ${ }^{66}$ The controversy was up and running and surfaced regularly over the next two years. The controversy culminated in the summer of 1955 when Rajagopalachari published a pamphlet entitled BCG - Why I Oppose It. As a response to Rajagopalachari's pamphlet the Government of Madras published a counter-pamphlet entitled Truth about BCG. Why Government Have Launched a Mass Campaign, which attempted to address both the scientific debate and the popular concerns about the vaccine. 
Rajagopalachari's opposition resonated throughout India and caused a dramatic, if relatively short-lived, drop in the number of people reached by the BCG teams over the summer of 1955. It made the biggest impact in South India - particularly in Madras State - where it seems to have adversely affected campaign figures until $1957 .^{67}$

The opposition to BCG was complex and although Raman and Rajagopalachari agreed on many things, they also differed in important aspects of their opposition. I therefore analyse the opposition to BCG through the identification of four overlapping and interdependent 'strains'. First, specific criticism was directed against the BCG vaccine. This 'strain' featured prominently because - in contrast to the vaccine against smallpox - the value of BCG was contested among scientists. ${ }^{68}$ BCG was the first vaccine based on attenuated live bacteria, and it had been connected with the death of seventy-six infants in the German city of Lübeck in 1930. By 1948 medical experts agreed that BCG was safe, but suspicion lingered on and was also employed by its Indian opponents. Raman explicitly referred to the tragedy in Lübeck, while Rajagopalachari indirectly utilised the safety issue by declaring: 'What one cannot, however, agree to is the injection into tens of thousands of our children, of live bacilli when we have no authority to claim certainty of harmlessness on the basis of the attenuation of those bacilli. ${ }^{69}$

If experts considered BCG safe by 1948, they continued to disagree on its protective value. Many held that the vaccine did not provide significant protection, and its Indian opponents noted that it was not used in the USA and that the British medical authorities were only slowly adopting it. In a letter to The Hindu on 17 May 1955 Rajagopalachari formulated his criticism in two questions, combining the quite different reservations against the vaccine: '(1) Is there no danger in mass inoculation by live BCG? (2) Does the attenuated Bovine tubercle bacillus create an immunity against the normal human infection? ${ }^{70}$ In this way the BCG vaccine was simultaneously portrayed as both dangerously virulent and hopelessly ineffective. These shortcomings together with the fact that BCG was not used on a mass scale in the countries assisting the Indian campaign obviously opened the guineapig issue. In 1949 newspapers quoted Raman's exclamation: 'I strongly protest in the name of India ... against our boys and girls being made a sort of cannon-fodder and treated like guinea-pigs for the sake of experimentation. ${ }^{, 71}$ 
The specific uncertainties connected to BCG provided, however, also a platform for a discussion of more general issues. For Raman this was the flawed, techno-centric strategy behind a narrow, single-disease campaign. What India needed, Raman argued, was 'environmental engineering': broad health programmes concentrating on improving the basic living conditions of the Indian poor. This was the second strain of opposition, and it was introduced in Raman's first editorial against BCG from November 1948:

Of what earthly use is BCG in the present living condition of the Indian masses; every moment of their lives, they take a dose of infection; they continue to take in heroic doses of it day in and day out ... The Minister of Health can just as well pass a resolution that every home should be a BCG factory and every hospital a tuberculosis hospital. ${ }^{72}$

Raman later repeated his criticism of the narrow vaccination strategy; and he did so by invoking two interesting authorities in the debate over public health in independent India:

We would give the first and foremost priority to the improvement of nutritional and environmental conditions. The Bhore Committee has said so. Long before the Bhore Committee, Mahatmaji said so. The fact, however, is that there is hardly a single Health Minister in any province today, who is troubled by the disparity between official policies and the Mahatmaji's teachings. ${ }^{73}$

The reference to the authoritative Bhore Committee was not surprising. The report had been published only three years earlier, and Raman shared a belief in the doctrine of 'social medicine' with the committee. He wanted the Indian state to intervene in public health through comprehensive programmes of environmental engineering that addressed basic health issues such as village sanitation and clean drinking water. The reference to Gandhi was less straightforward, but perhaps more powerful. Raman employed Gandhi's famous remark about western medicine as 'the essence of black magic', although he did not share this view. When Raman invoked Gandhi's name, it was not as the critic of western medicine but as the ardent supporter of nutrition and sanitation. To Raman BCG was a dubious and untested 'technological fix'. By adopting it the young Indian state had betrayed the hopes held for a new departure in public health as well as the ideals of the Mahatma. 
Rajagopalachari did not join Raman on this issue. If Raman felt the state intervened too little and too superficially in public health, Rajagopalachari felt it intervened too much. After stepping down as Chief Minister in 1954, he increasingly fell out with the Nehruvian version of socialism and the omnipotent role of the state, and in 1959 he became the leading figure in the establishment of the conservative anti-statist Swatantra Party. ${ }^{74}$ This suggests that we understand his opposition to BCG vaccination as part of this transformation and consequently that it was directed as much against the policies pursued in Nehru's India, as against the controversial vaccine itself. A conservative uneasiness with the increasing role of the Indian state was, therefore, a third 'strain' underpinning the opposition to BCG.

A final and obvious 'strain' was nationalism. Inevitably, the adoption of a disputed and possibly second-rate vaccine provoked nationalist sentiments in the newly independent state. India had finally emerged as a nation in its own right and on a par with western countries; it now demanded the same standard of public health remedies. The guinea-pig issue turned up again; this time accompanied by concerns about India's status as a nation in relation to other communities. Raman remarked that experiments with BCG had been conducted 'on guinea-pigs, calves and American Indians ... I am driven by the irresistible conclusion that the authorities are exposing the people of this country to be utilised by research workers for their benefit. ${ }^{75}$ Rajagopalachari joined him by claiming that, 'Indian children are being offered for mass expectation on the same plan as was put in operation among the people in warravaged areas and uncivilised dependent communities. ${ }^{176}$ As members of a new and sovereign nation, neither Raman nor Rajagopalachari could accept being treated like American Indians or 'dependent communities'! One of Rajagopalachari's many correspondents made the point even clearer: 'The Britishers would never have done it, not even in Kenya. ${ }^{77}$ BCG was again seen as an act of betrayal, this time against the newly won nationhood.

\section{Immunisation as neo-colonial conspiracy}

After the BCG controversy died down towards the end of the 1950s, the following three decades seems to have witnessed little visible and vocal opposition to immunisation. Towards the end of the 1980s, 
however, a new sceptical voice made itself heard, at least among academics and bureaucrats. This voice belonged to Debabar Banerji. Having graduated from Calcutta Medical College in 1953, Banerji's career took an unusual turn, when he was employed as a sociologist attached to the National Tuberculosis Institute in Bangalore in 1961. He joined Jawaharlal Nehru University (JNU) in Delhi in 1972 where he became Professor at the Centre of Social Medicine and Community Health.

Banerji's criticism of immunisation in India targeted the UIP. In two near identical articles from 1990 Banerji disputed the Indian government's claim that vaccination was one of the most cost-effective health interventions and accused it of launching a massive, expensive and very complicated programme ... without even finding out what the problem was. ${ }^{57}$ Banerji raised a range of issues: the programme lacked, 'the baseline epidemiological data' on the six diseases that it was supposed to cover, internal evaluation was flawed, the 'cold chain' supposed to keep vaccines potent in the field was not sufficiently monitored, and attempts were made to 'cover up' the dismal performance, which - according to Banerji - did not reach the target of 85 per cent coverage in any of the Indian states. ${ }^{79}$ The UIP was therefore grouped with other 'ill-conceived and ill-designed, techno-centric, target oriented and time bound programmes.

In 2004 Banerji applied a similar criticism to the Global Programme for Polio Immunisation (GPPI), and its Indian avatar, the Pulse Polio Programme. This time he was backed by several other critics, many of them based at his former workplace, The Centre for Social Medicine and Community Health at JNU. According to William Muraskin's instructive account of the global effort to eradicate polio, India gave rise to 'the most powerfully argued and cogent' protest against this enterprise. It was the existence of a sufficiently large, critical mass of highly educated medical men in India that enabled the formation of a group labelled the 'Indian dissenters' by Muraskin. ${ }^{81}$ As a central voice among these dissenters, Banerji pointed out that, seen from non-western regions, polio was not a sufficiently important health problem to merit a costly eradication effort. By following the lead taken by western countries, the Indian authorities failed 'to attend to far more important health problems. ${ }^{82}$ Immunisation against polio continued on the flawed strategy of the UIP and the GPPI was, he concluded, an expensive, epidemiologically unsound disaster: 'It should never have been 
attempted. It has diverted attention from some of the most pressing problems of child mortality and morbidity among the poor in the world. It has turned out to be highly expensive. It presents unsurmountable problems of implementation. ${ }^{83}$

While the other members of 'Indian dissenters' group continued to criticise the campaign against polio based on clinical and epidemiological considerations, ${ }^{84}$ Banerji's position had always included elements far beyond epidemiology. In one of his articles, he situated his specific criticism of immunisation in the larger context of asymmetrical, neo-colonial relations of power:

In the existing immoral and unethical North-South divide, which is based on unequal terms of exchange, by imposing such programmes on the South the North seems to come back to the South with a tiny fraction of what it has plundered from it and, adding insult to injury, seems to be telling the South condescendingly: 'Here we come with our technological magics. We have a magical wand to remove your health problems. What does it matter if you are forced to live under degrading conditions of poverty, illiteracy, exploitation, and social injustice? After all, you and your children are alive! Look how we have raised your life expectancy. ${ }^{85}$

This echoed both the prose of the Bhore Committee and of Raman's arguments that immunisation was a 'cheap' technological fix offered to post-colonial countries as a poor substitute for real progress in public health. Like Raman, Banerji was an ardent advocate of primary health care, and - unlike Raman - he was able persistently to refer to the most powerful international manifestation of that approach: WHO's 1978 Alma-Ata Declaration. To Banerji the Declaration was a 'watershed' in the history of public health and a 'major victory for the masses of people in the world,'

In 2004 Banerji published an interesting article, in which he developed these views into a historical narrative of the development of public health in India. The article set out by describing the introduction of western medicine as one of the adverse effects of colonial rule in India. The priority given to western medicine had an adverse effect on the already stagnant indigenous traditions of medicine. Out of this misery grew, however, 'a number of internally generated - "endogenous" movements for developing alternative approaches to improving people's health. ${ }^{, 87}$ Banerji identified three such 'home-grown' alternatives: Gandhi's promotion of naturopathy, hygiene and environmental sanitation; 
the distinguished Indian physician and nationalist politician, B. C. Roy, who advocated integration of western medicine and indigenous traditions; and the sub-committee on health of the National Planning Committee established in 1938 by the Indian National Congress. According to Banerji the latter had 'made an attempt to bring together the ideas for an alternative health service for the country. ${ }^{\prime 8}$ Invoking these "internally generated' alternatives to colonial, western style medicine, Banerji introduced the issue of an Indian distinctiveness that called for a particular, nationally appropriate health strategy.

In his treatment of the health services in independent India, Banerji applauded the priorities and visions of the Bhore Committee and regarded its report as an authoritative document. Although the early years of independence were tough, the new regime was - Banerji argued - compelled to listen to the people in the planning of public health and 'India could develop an endogenous, alternative body of knowledge that was more suited to its prevailing social, cultural, economic, and epidemiological conditions. ${ }^{89}$

In a rare endorsement of the achievement of public health policies in India between 1947 and 1977, Banerji narrated how primary health centres were set up (as advised by the Bhore Committee) and how programmes such as the National Tuberculosis Programme (to which Banerji was associated in his early career) received world-wide attention because they resisted the imposition of a western 'pre-fabricated technological package.90 Banerji even vouched for the problematic DDT-based National Malaria Eradication Programme; often viewed as the prototype of a techno-centric, vertical disease control programme. ${ }^{91}$ By 1977, 'India thus came quite close to the Alma-Ata Declaration on Primary Health Care', which clearly epitomised Banerji's favoured medical strategy. In Banerji's narrative, a new approach to the study of public health was developed, which was 'specially tailored for a country such as India. ${ }^{92}$

Soon after, however, the 'fall from grace' occurred. Before the ink on the Alma-Ata declaration had dried, western countries backed down from the promises made in Kazakhstan. Primary health care was turned into selective primary health care, which focused more narrowly on the specific fields of growth monitoring, oral rehydration, breastfeeding, and - notably - childhood immunisation. To Banerji this amounted to a 'retreat from the commitments made at Alma-Ata. ${ }^{93}$ The Indian 
government's launch of the UIP was - both in Banerji's specific criticism of the programme and in his larger narrative - presented as a result of this retreat from and counter-attack on the principles of primary health care. Implementation of Pulse Polio in India simply added insult to injury.

Two things should be emphasised in Banerji's views on immunisation. First, he never rejected the practice of immunisation as such; his criticism was always about the way in which it was conducted. Although the Oral Polio Vaccine was controversial and had many flaws, Banerji did not - by contrast to the critics of BCG - delve extensively into this issue. ${ }^{94}$ Similarly, he ended his criticism of the UIP on the note that: 'The question is not of rejecting all technology; the question is to see through the dangers of the market forces in both the North and the South. ${ }^{.95}$ Second, while his attacks on the IUP and polio eradication programmes were 'universal', in the sense that he positioned himself as speaking on behalf of the poor throughout the developing world, ${ }^{96}$ his later and more historically informed reflections introduced the notion of a specifically Indian, 'endogenous' tradition of public health that was able to devise strategies particularly suited to the demographic, social and cultural characteristics of Indian society. These strategies excluded the wholesale acceptance of immunisation programmes designed by rich, western countries and their adherents in international organisations. While Banerji's aggressive rhetoric might have had a limited impact on the actual public health policy in India, it does illustrate the persistence of the notion that something in Indian society makes immunisation particularly problematic there.

\section{Conclusion}

The history of immunisation in India is mainly about some of the world's most extensive programmes and about millions of people accepting the introduction of micro-organisms into their bodies for preventive purposes. This chapter has, by contrast, focused on four instances of opposition to immunisation. While articulate opposition represents the exception and has largely been an elite phenomenon, it points to a least two important tensions in modern Indian society: between universal science and cultural distinctiveness and between international intervention and national integrity. 
The four cases analysed each provide a distinctive illustration of how immunisation and the opposition to it was culturally constructed and linked to an imagined Indian nation. The opposition to vaccination against smallpox in Billimoria's pamphlet was as imported as the practice of vaccination itself: even if vaccination harmed the national body, the pamphlet looked to Britain both for arguments and evidence. While Gandhi was in agreement with many of the arguments employed by anti-vaccinationists in Britain, his emergence as the leading representative of the Indian nation, and his general anti-modernist rhetoric meant that his reservations against immunisation were bound to be read as a culturally embedded rejection of a medical practice that was both immoral and unsuited to Indian conditions. With reference to Gandhi, Indians could display their 'Indianness' by rejecting immunisation, and later both Raman and Banerji did indeed invoke his name as they discarded externally designed immunisation programmes.

While independent India readily embraced immunisation and largely followed the stance taken by WHO and other international organisations, opposition continued to be articulated. BCG vaccination was countered by a complex set of arguments in the first decade after independence. In the present context the most salient feature was that mass vaccination with BCG was constructed as a betrayal of both Indians' expectations to be offered public health interventions that matched those in the West, and of their newly won nationhood. The theme of betrayal also featured in the last of the cases analysed, this time of the principles of primary health care enshrined in the Alma-Ata declaration. Debabar Banerji saw the way in which immunisation was implemented as a manifestation of continued unequal neo-colonial relations of power. Moreover, he developed a historical narrative in which global immunisation programmes were opposed to a specifically 'endogenous', Indian way of approaching public health challenges.

From these examples it is clear that Paul Greenough was correct when he remarked that 'encounters with government vaccinators are never about immunization alone. ${ }^{97}$ Three of the cases analysed feature the notion of a distinctive 'Indianness' that made imported ways of conducting immunisation particularly problematic. This suggests that David Arnold's contention that vaccination in the nineteenth century was constructed as a site of conflict between malevolent British intent 
and something 'Indian' is also relevant for the twentieth century; not so much for the ordinary Indian, but for the Indian elite that was concerned with the formulation and preservation of a distinctive national identity. To the voices analysed in this chapter immunisation was not building the nation, but threatened to destroy it.

\section{Acknowledgements}

I am particularly grateful to Rajib Dasgupta for comments on a first draft of this chapter. The responsibility for any errors or misjudgements remains with me.

\section{Notes}

1 D. Wujastyk, “'A Pious Fraud": The Indian Claims for Pre-Jennerian Smallpox Vaccination', in G. J. Meulenbed and D. Wujastyk (eds), Studies on Indian Medical History (Groningen: Egbert Forsten, 1987), pp. 131-67, on p. 134.

2 Ibid., pp. 164-7.

3 N. Brimnes, 'Variolation, Vaccination and Popular Resistance in Early Colonial South India', Medical History, 48:2 (2004), pp. 199-228.

4 Quoted in Wujastyk, 'A Pious Fraud', p. 151. See also D. Arnold, Colonizing the Body. State Medicine and Epidemic disease in Nineteenth-Century India (Berkeley: University of California Press, 1993), p. 136.

5 P. R. Greenough, 'Variolation and Vaccination in South Asia c.1700-1865: A Preliminary Note', Social Science and Medicine, 14D (1980), pp. 345-47; Arnold, Colonizing the Body, p. 139; S. Bhattacharya, M. Harrison and M. Worboys, Fractured States: Smallpox, Public Health and Vaccination Policy in British India 1800-1947 (Hyderabad: Orient Longman, 2005), p. 59.

6 Arnold, Colonizing the Body, pp. 140-1; Bhattacharya et al., Fractured States, pp. 178-203.

7 R. Jeffery, The Politics of Health in India (Berkeley: University of California Press, 1988), p. 96.

8 Arnold, Colonizing the Body, pp. 197-8, 221-3.

9 Ibid., pp. 143-4.

10 Bhattacharya et al., Fractured States, pp. 66-9, 72.

11 Arnold, Colonizing the Body, pp. 221-3.

12 Bhattacharya et al., Fractured States, pp. 203-17.

13 Report of the Health Survey and Development Committee 2 (Calcutta: Government of India Press, 1946), pp. 1-4. 
14 Ibid., quoted from pp. 169 and 171.

15 Ibid., pp. 179, 185

16 Sanjoy Bhattacharya, Expunging Variola. The Control and Eradication of Smallpox in India 1947-77 (Hyderabad: Orient Longman 2006), pp. 50, 99

17 Government of India, 'Second Five Year Plan', chapter 25 Health, para 37, at http://planningcommission.nic.in/plans/planrel/fiveyr/welcome.html (accessed 5 June 2013). N. Brimnes, 'Another Vaccine, Another Story: BCG Vaccination Against Tuberculosis in India, 1948 to 1960', Ciência \& Saúde Coletiva, 16:2 (2011), pp. 397-407.

18 F. Fenner et al., Smallpox and its Eradication (Geneva: WHO 1988), pp. $366-71$.

19 R. N. Basu, Z. Jezek and N. A. Ward, The Eradication of Smallpox from India (New Delhi: WHO, 1979), pp. 21-8.

20 Bhattacharya, Expunging Variola, p. 133. For the 44.9\% figure, see p. 126. See also Basu, The Eradication of Smallpox, p. 28.

21 Bhattacharya, Expunging Variola, pp. 176-210; Basu, The Eradication of Smallpox, pp. 29-32.

22 Bhattacharya, Expunging Variola, pp. 215, 230; Basu, The Eradication of Smallpox, pp. 32-4.

23 WHO/UNICEF, State of World's Vaccines and Immunization (Geneva: WHO, 1996), pp. 11-14; S. K. Pradhan, 'Time to Revamp the Universal Immunization Program in India', Indian Journal of Public Health, 54 (2010), pp. 71-4, www.ijph.in/text.asp?2010/54/2/71/73273 (accessed 7 June 2013); Ministry of Health and Family Welfare, National Vaccine Policy (Delhi: Government of India, 2011); V. M. Vashishtha and P. Kumar, '50 Years of Immunization in India: Progress and Future', Indian Pediatrics, 50:1 (2013), pp. 11-118, on p. 112.

24 Pradhan, 'Time to Revamp'.

25 Vashishtha and Kumar, '50 Years of Immunization', p. 112; S. K. Mittal, 'Pulse Polio Program - A National Perspective, Indian Journal of Pediatrics, 63:1 (1996), pp. 1-8; P. Chatterjee, 'How India Managed to Defeat Polio', $B B C$ News India, 13 January 2014, www.bbc.co.uk/news/world-asiaindia-25709362 (accessed 18 February 2014).

26 M. Nichter, 'Vaccinations in South Asia: False Expectations and Commanding Metaphors', in M. Nichter (ed.), Anthropology and International Health: South Asian Case Studies (Dordrecht, Boston: Kluwer Academic Publishers, 1989), pp. 200-11; M. Nichter, 'Vaccinations in the Third World: A Consideration of Community Demand', Social Science and Medicine, 41:5 (1995), pp. 617-32.

27 Basu, The Eradication of Smallpox, pp. 112-14; P. R. Greenough, 'Intimidation, Coercion and Resistance in the Final Stages of the South Asian 
Smallpox Eradication Campaign, 1973-1975', Social Science and Medicine, 41:5 (1995), pp. 633-45.

28 Bhattacharya, Expunging Variola, pp. 237-8.

29 N. F. Billimoria, 'Vaccination: A Fallacy', in Vaccination and Small-pox (Bombay: Bombay Humanitarian League, 1921), pp. 9-10, 20-6.

30 Ibid., pp. 29, 33.

31 Ibid., p. 18.

32 L. Loat, 'Vaccination and Small-Pox in India', in Vaccination and Small-pox (Bombay: Bombay Humanitarian League, 1921), p. 46.

33 Ibid., pp. 39-41.

34 Ibid., pp. 42, 46.

35 Sometimes also referred to as The Health Guide. See M. K. Gandhi, A Guide to Health (Madras: S. Ganesan, 1921).

36 'Hind Swaraj', in Collected Works of Mahatma Gandhi (hereafter CWMG) (New Delhi: Government of India, 1959-84), X, pp. 6-64, on p. 35.

37 Billimoria, 'Vaccination: A Fallacy', p. 11.

38 'General Knowledge About Health - XXIV', Indian Opinion (14 June 1913), in CWMG, XII, p. 111.

39 'Village Improvement', Young India (14 November 1929), in CWMG, XLII, pp. 146-7.

40 'Notes', Young India (18 July 1929), in CWMG, XLI, p. 192.

41 'Smallpox and Cholera', Navajivan (30 June 1929), in CWMG, XLI, p. 141; 'Letter to Manilal and Sushila Gandhi' (30 June 1929), in CWMG, XLI, p. 146.

42 'Hind Swaraj', in CWMG, X, pp. 35-6. Letter to Henry S. L. Polak, 14. October 1909, in CWMG, IX, p. 479.

43 'Speech at opening of Tibbi College, Delhi, Bombay Chronicle (15 February 1921), in CWMG, XIX, p. 358.

44 'Interview to Capt. Strunk', Harijan (3 July 1937), in CWMG, LXV, p. 361.

45 J. S. Alter, Gandhi's Body. Sex, Diet and the Politics of Nationalism (Philadelphia: University of Pennsylvania Press, 2000), p. 20. S. S. Amrith, Decolonizing International Health. India and Southeast Asia 1930-65 (Basingstoke: Palgrave Macmillan, 2006), p. 33.

46 'A National Defect', Young India (25 April 1925), in CWMG, XL, p. 283.

47 'General Knowledge about Health - I', Indian Opinion (4 January 1913), in CWMG, XI, p. 428.

48 'Speech at opening of Tibbi College, Delhi, Bombay Chronicle (15 February 1921), in CWMG, XIX, p. 357.

49 See, for instance, 'Implications of Constructive Programme', Harijan (18 August 1940), in CWMG, LXXII, pp. 378-81. 
50 'Smallpox and Cholera', Navajivan (30 June 1929), in CWMG, XLI, p. 141. Gandhi did refer implicitly to the experience of Leicester. 'General Knowledge About Health - XXV', Indian Opinion (21 June 1913), in CWMG, XII, p. 116.

51 'Speech at Mayavaram', The Hindu (15 September 1927), in CWMG, XXXIV, p. 529; 'Interview to Capt. Strunk', Harijan (3 July 1937), in CWMG, LXV, p. 361. For examples of Gandhi's scepticism towards the ayurvedic tradition of medicine, see CWMG, LXXVI, pp. 45, 161-2, 201-2, 257.

52 'General Knowledge about Health - XXV', in CWMG, XII, pp. 115-17.

53 'Hind Swaraj', in CWMG, X, p. 36. Emphasis added.

54 'Discussion with Dr Chesterman', Harijan (25 February 1939), in CWMG, LXVIII, p. 420.

55 'Speech at Prayer Meeting', Delhi (2 June 1947), in CWMG, LXXXVIII, p. 62.

56 This section is adapted from the more detailed treatment of the opposition to BCG vaccination in C. W. McMillen and N. Brimnes, 'Medical Modernization and Medical Nationalism: Resistance to Mass Tuberculosis Vaccination in Postcolonial India, 1948-1955', Comparative Studies in Society and History, 52:1 (2010), pp. 180-209. For a later and further-developed version of this analysis, see also Niels Brimnes, Languished Hopes: Tuberculosis. The State and International Assistance in Twentieth-century India, (Hyderabad: Orient BlackSwan, 2016), pp. 148-82.

57 'Press Note', printed in Indian Medical Gazette (January 1948), pp. 50-1.

58 'First Five Year Plan', chapter 32 Health, para. 37; 'Second five Year Plan, chapter 25 Health, para. 37, both at http://planningcommission.nic.in/ plans/planrel/fiveyr/welcome.html (accessed 5 June 2013).

59 People's Health, 3:2, p. 53.

60 Indian Express (5 February 1949); The Hindu (14 February 1949). Articles that referred to Raman's critique of BCG from Indian Express, Nagpur Times and Sunday Times were all reproduced in People's Health, 3:5, pp. 206-8.

61 People's Health, 3:5, p. 222.

62 I assume Raman is the author of the editorial, which has no signature.

63 Raman stopped publishing People's Health in 1951, most likely for financial reasons.

64 A. Copley, The Political Career of C. Rajagopalachari 1937-1954. A Moralist in Politics (Madras: Macmillan, 1978), p. 246.

65 Tamil Nadu State Archive, Chennai, Health Department, 1216, 1953; Nehru Memorial Library, New Delhi, C. Rajagopalachari Papers, Instalment VI-XI, Subject files no. 28. 
66 The Hindu (15 and 17 May 1955).

67 P. Larsen (UNICEF, New Delhi) to T.G. Davies (UNICEF, New York) 17 September 1955. UN Archives (UNICEF), Box CF/RA/BX/PD/1962/ T008, folder A124. See also the numbers given in Amrith, Decolonizing International Health, pp. 141-2.

68 For the controversial history of BCG and the official WHO position on its use, see N. Brimnes, 'BCG Vaccination and WHO's Global Strategy for Tuberculosis Control 1948-1983’, Social Science and Medicine, 67 (2008), pp. 863-73.

69 The Hindu (17 May 1955). For Raman's reference to Lübeck, see The Hindu (14 February 1949). Also reproduced in People's Health, 3, p. 204.

70 The Hindu (17 May 1955).

71 Indian Express (5 February 1949). See also The Hindu (5 February 1949). Both reproduced in People's Health, 3:5, p. 198.

72 People's Health, 3:2, p. 53.

73 People's Health, 3:5, p. 188.

74 Copley, The Political Career, pp. 14, 161, 236; H. L. Erdman, The Swatantra Party and Indian Conservatism (Cambridge: Cambridge University Press, 1967), p. 65.

75 The Hindu (14 February 1949). Important trials with BCG had been carried out on American Indians from the 1930s. See, Christian W. McMillen, " "The Red Man and the White Plague": Rethinking Race, Tuberculosis, and American Indians, ca.1890-1950', Bulletin of the History of Medicine, 82:3 (2008), pp. 608-45.

76 C. Rajagopalachari, B.C.G. - Why I Oppose It, n.p. [1955], p. 1.

77 S. Soundararajan (Madras) to C. Rajagopalachari (Madras), 3 August 1955. Nehru Memorial Library, Delhi, C.Rajagopalachari Papers, instalment V, Subject file no. 135.

78 D. Banerji, 'Politics of Immunisation Programme', Economic and Political Weekly, 25:14 (1990), p. 715; D. Banerji, 'Crash of the Immunization Programme: Consequences of a Totalitarian Approach', International Journal of Health Services, 20:3 (1990), pp. 501-10.

79 Banerji, ‘Crash', pp. 505-6.

80 Banerji, 'Politics', p. 717.

81 W. Muraskin, Polio Eradication and its Discontents. A Historian's Journey Through an International Health (un)Civil War (Hyderabad: Orient BlackSwan, 2012), pp. 94-128. Quoted from p. 94.

82 D. Banerji, 'Global Programme of Polio Eradication in India', pp. 1-26, quoted from p. 8. This document is dated 12 April 2004 and posted, though without the references, at the website of the International Association of Health Policy. See: wwwhealthp.org/node/17 (accessed 13 May 2013). 
83 Ibid., p. 19.

84 C. Sathyamala et al., 'Polio Eradication Initiative in India: Deconstructing the GPEI', International Journal of Health Services, 35:2 (2005), pp. 361-83.

85 Banerji, 'Crash', p. 507.

86 D. Banerji, 'Technocentric Approach to Health. Western Responses to Alma-Ata', Economic and Political Weekly, 31:28 (1986), pp. 1233-4; Banerji, 'Politics', p. 715; Banerji, 'Crash', p. 501.

87 D. Banerji, 'The People and Health Service Development in India: A Brief Overview', International Journal of Health Services, 34:1 (2004), pp. 123-42. Quoted from p. 126.

88 Banerji, 'The People', p. 127.

89 Ibid., p. 130.

90 Ibid., p. 131. See also Banerji, 'Global Programme’, p. 2.

91 Banerji, 'Global Programme', p. 20.

92 Banerji, 'The People', p. 132.

93 Banerji, 'Crash', p. 502; Banerji, ‘Technocentric Approach', p. 1233.

94 On the problems with the Oral Polio Vaccine (OPV), see Muraskin, Polio Eradication, pp. 12-18.

95 Banerji, 'Crash', p. 507; Banerji, 'Politics', p. 717. Muraskin, Polio Eradication, p. 124, note 42.

96 Muraskin, Polio Eradication, p. 94.

97 Greenough, 'Intimidation', p. 633. 